\title{
ALTERNATYWNA PROCEDURA ANALITYCZNO- NUMERYCZNA W EUROKODOWYM PROJEKTOWANIU STALOWYCH ELEMENTÓW Z BOCZNYMI USZTYWNIENIAMI DYSKRETNYMI
}

\begin{abstract}
Przedstawiono alternatywną do eurokodowej propozycję analityczno-numeryczną oceny nośności stalowych elementów osiowo ściskanych i zginanych względem osi większej bezwładności przekroju. Niniejszy artykuł stanowi kontynuację badań autorów prowadzonych dotychczas tylko w odniesieniu do elementów bez usztywnień pośrednich, a rozszerzonych na obecnym etapie do elementów z pośrednimi usztywnieniami dyskretnymi. Zaproponowano uogólnienie sformułowania Ayrton-Perry'ego do elementów równocześnie ściskanych i zginanych, w postaci analogicznej do przyjętej w PN-EN 1993-1-1 lecz odnoszącej się tylko do elementów ściskanych lub zginanych. Na wybranych przykładach porównano wyniki otrzymane $\mathrm{z}$ proponowanego alternatywnego podejścia analitycznonumerycznego $\mathrm{z}$ wynikami uzyskanymi $\mathrm{z}$ interakcyjnych formuł eurokodowych, w których współczynniki interakcji wyznaczano Metodą 1 oraz Metodą 2.
\end{abstract}

Słowa kluczowe: dwuteownik stalowy, zginanie i ściskanie, nośność na wyboczenie, uogólnione sformułowanie Ayrton-Perry, dyskretne usztywnienia boczne i przeciwskrętne

\section{Wprowadzenie}

Właściwa ocena nośności dwuteowych bisymetrycznych elementów stalowych, ściskanych i jednokierunkowo zginanych względem osi większej bezwładności przekroju jest bardzo istotna w projektowaniu konstrukcji stalowych. Bardzo często elementy płaskich układów ramowych są podparte bocznie (w płaszczyźnie prostopadłej do płaszczyzny ramy) i/lub przeciwskrętnie przez inne drugorzędne elementy nośne, jak np. belki stropowe, płatwie dachowe lub

1 Autor do korespondencji / corresponding author: Zbigniew Stachura, Politechnika Warszawska, Wydział Inżynierii Lądowej, Zespół Konstrukcji Metalowych, Armii Ludowej 16, 00-637 Warszawa, Polska, z.stachura@il.pw.edu.pl

${ }^{2}$ Marian Giżejowski, Politechnika Warszawska, Wydział Inżynierii Lądowej, Zespół Konstrukcji Metalowych, Armii Ludowej 16, 00-637 Warszawa, Polska, m.gizejowski@il.pw.edu.pl 
rygle ścienne. Tego typu podparcie może mieć charakter sztywny, przegubowy lub podatny.

Zgodnie z PN-EN 1993-1-1 [10], przy projektowaniu elementów ściskanych stałą siłą podłużną $N_{E d}$ i jednokierunkowo zginanych względem osi większej bezwładności przekroju $y-y$ momentem o maksymalnej wartości $M_{y, E d}=M_{y, E d, \max }$ sprawdzenie nośności polega na weryfikacji dwóch stanów granicznych: 1) nośności przekroju oraz 2) nośności elementu z uwzględnieniem utraty stateczności ogólnej (wyboczenia ze zwichrzeniem). W odniesieniu do weryfikacji nośności elementu wykorzystuje się formuły interakcyjne w których współczynniki interakcji można określić zgodnie z Metodą 1 [2] lub Metodą 2 [9], która jest rekomendowana w załączniku krajowym normy [10]. W obu metodach nośność przy wyboczeniu oraz nośność przy zwichrzeniu wyznacza się oddzielnie i niezależnie od siebie na podstawie przyjętego w [10] modelu Ayrton-Perry'ego $[1,15]$ i koncepcji zastępczych imperfekcji geometrycznych z amplitudą według propozycji Maquoi-Rondala [12]. Alternatywnie do wymienionych powyżej warunków weryfikacji nośności, norma [10] wprowadza również możliwość oceny nośności zgodnie z tzw. metodą ogólną [3], a jej praktyczną aplikację w projektowaniu płaskich układów ramowych przedstawiono $\mathrm{w}[6]$.

Współcześnie trwają prace badawcze w opracowaniu uogólnienia podejścia Ayrton-Perry'ego w ocenie nośności elementu jednocześnie ściskanego i zginanego $[4,5,7,11,14]$. W większości prace te jednak ograniczane są głównie do elementów bez dodatkowych usztywnień bocznych.

$\mathrm{W}$ odniesieniu do elementów z dodatkowymi pośrednimi dyskretnymi podparciami bocznymi i/lub przeciwskrętnymi, w praktyce projektowej ocena nośności zgodnie z [10] przebiega analogicznie jak w odniesieniu do elementów jednoprzęsłowych niestężonych bocznie i/lub przeciwskrętnie, przy czym do oceny nośności wybiera się najniekorzystniejszy segment pomiędzy usztywnieniami bocznymi.

Niniejszy artykuł jest kontynuacją badań $[4,5,7]$ uogólnienia podejścia Ayrton-Perry'ego w ocenie nośności elementów swobodnie podpartych poddanych jednoczesnemu ściskaniu i jednokierunkowemu zginaniu w płaszczyźnie większej bezwładności przekroju rozszerzonych w obecnym etapie o elementy z dodatkowymi pośrednimi dyskretnymi podparciami bocznymi i przeciwskrętnymi o charakterze sztywnym. Na wybranych przykładach stalowych elementów wykonanych $\mathrm{z}$ gorącowalcowanych dwuteowników o przekrojach klasy 1 i 2 porównano wyniki otrzymane $\mathrm{z}$ proponowanego w niniejszym artykule podejścia z wynikami uzyskanymi z formuł eurokodowych, w których współczynniki interakcji wyznaczono Metodą 1 oraz Metodą 2. 


\section{Koncepcja oceny nośności na podstawie uogólnionego modelu Ayrton-Perry'ego}

Praktyczną interpretację graficzną proponowanego alternatywnego podejścia oceny nośności elementów stalowych przedstawiono na rysunku 1 . Rysunek 1a) dotyczy propozycji w odniesieniu do elementów z pośrednimi podparciami bocznymi i przeciwskrętnymi. Porównawczo na rysunku 1b) przedstawiono propozycję autorów $[4,5,7]$ opracowaną w odniesieniu do elementów bez stężeń pośrednich. Na rysunku 1: $\bar{\lambda}_{L T}$ jest smukłością względną przy zwichrzeniu, $\bar{\lambda}_{i}$ jest zaś smukłością względną, która daje najmniejszy współczynnik redukcyjny $\chi_{i}$ przy ściskaniu, tzn. $\chi_{i}=\min \left(\chi_{y}, \chi_{z}, \chi_{T}\right)$ w odniesieniu do wyboczenia giętnego względem osi $y-y\left(\bar{\lambda}_{y}\right)$, wyboczenia giętnego względem osi $z-z\left(\bar{\lambda}_{z}\right)$ lub wyboczenia skrętnego względem osi $x-x\left(\bar{\lambda}_{T}\right)$, przy czym wskazane smukłości względne i współczynniki redukcyjne wyznacza się zgodnie $\mathrm{z}[10,13]$.

Aktualny stan wytężenia przekroju elementu reprezentowany jest na rysunku 1 przez punkt $A_{E d}$. Punkt $A_{\text {cr }}$ na rysunku $\left.1 b\right)$ odpowiada sprężystemu wyboczeniu giętno-skrętnemu elementu idealnego zaś na rysunku 1a) odpowiada zwichrzeniu sprężystemu elementu idealnego, poddanego zginaniu. Na rysunku 1 b) punkt $A_{i p, R k}$ odpowiada zniszczeniu elementu idealnego ściskanego i zginanego przy założeniu płaskiej postaci zginania, natomiast na rysunku 1a) punkt $\mathrm{A}_{\mathrm{Rk}}$ odpowiada zniszczeniu elementu nieidealnego ściskanego i zginanego względem osi $y-y$ (z imperfekcjami tylko $\mathrm{w}$ jednym kierunku, giętnymi zgodnie z osią $y-y$ lub $z-z$, lub skrętnymi względem osi $x-x$ ). W odniesieniu do elementów pośrednio stężonych zaproponowano „przeniesienie” efektów wyboczeniowych (giętnych lub skrętnych) ze stanu odpowiadającego punktowi $\mathrm{A}_{\mathrm{cr}}$ do stanu odpowiadającego punktowi $\mathrm{A}_{\mathrm{Rk}}$. W przypadku elementów pośrednio stężonych decyduje bowiem najczęściej wyboczenie w płaszczyźnie zginania, stąd też dużo bardziej istotniejsze są efekty interakcji wyboczenia i zginania, w odróżnieniu od elementów niestężonych pośrednio, w których o nośności decyduje giętno-skrętna forma utraty stateczności. Punkt $A_{b, R k}$ odpowiada nośności przy giętno-skrętnej formie technicznej utraty stateczności elementu nieidealnego, w wypadku:

a) elementów niestężonych poprzecznie z większym wpływem zwichrzenia,

b) elementów gęsto pośrednio stężonych $\mathrm{z}$ większym wpływem technicznego wyboczenia giętnego lub skrętnego.

Szczegółowy opis procedury postępowania odnoszący się do elementów bez usztywnień pośrednich przedstawiono w pracach autorów $[4,5,7]$. W dalszej części artykułu przedstawiono opis procedury odnoszący się do elementów z usztywnieniami pośrednimi. 

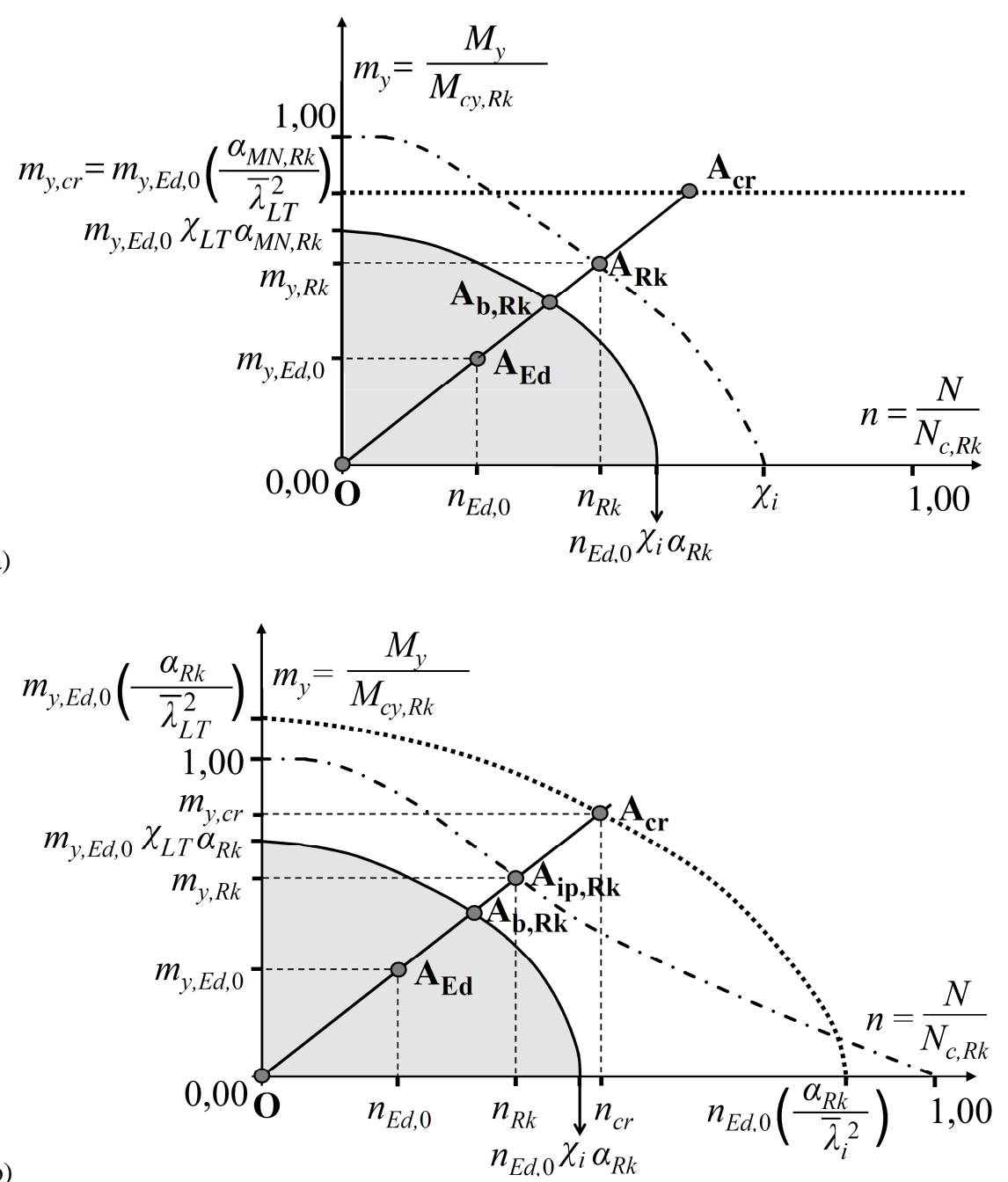

Rys. 1. Graficzna interpretacja propozycji uogólnienia formuły Ayrton-Perry’ego, a) elementy z pośrednimi dyskretnymi podparciami bocznymi i skrętnymi, b) elementy bez pośrednich usztywnień bocznych i skrętnych

Fig. 1. Graphical interpretation of the proposed generalized Ayrton-Perry formulation, a) members with intermediate discrete lateral-torsional restraints, b) members without intermediate lateral-torsional restraints

Mnożnik obciążenia $\alpha_{M, c r}$ odpowiadający stanowi krytycznemu przy zwichrzeniu zgodnie z rysunkiem 1a) odpowiada proporcji: 


$$
\alpha_{M, c r}=\frac{\overrightarrow{\mathrm{OA}_{\mathrm{cr}}}}{\overrightarrow{\mathrm{OA}_{\mathrm{Ed}}}}
$$

zaś mnożnik obciążenia $\alpha_{M N, R k}$ odpowiadający stanowi granicznemu ściskania i zginania II rzędu z imperfekcjami (bez uwzględnienia stanu zwichrzenia) odnosi się do ilorazu:

$$
\alpha_{M N, R k}=\frac{\overrightarrow{\mathrm{OA}_{\mathrm{Rk}}}}{\overrightarrow{\mathrm{OA}_{\mathrm{Ed}}}}
$$

Sposób wyznaczania mnożników $\alpha_{M, c r}$ (1) i $\alpha_{M N, R k}$ (2) przedstawiono w dalszej kolejności (patrz pkt. 3 niniejszej pracy).

Mnożnik obciążenia granicznego $\alpha_{b, R k}$ odpowiadający nośności charakterystycznej elementu nieidealnego ściskanego i zginanego z uwzględnieniem utraty stateczności giętno-skrętnej ma na rysunku 1a) następującą interpretację:

$$
\alpha_{b, R k}=\frac{\overrightarrow{\mathrm{OA}_{\mathrm{b}, \mathrm{Rk}}}}{\overrightarrow{\mathrm{OA}_{\mathrm{Ed}}}}
$$

przy czym jest wyznaczany z ogólnej zależności wynikającej z modelu AyrtonPerry'ego:

$$
\alpha_{b, R k}=\chi_{F T} \alpha_{M N, R k}
$$

Współczynnik redukcyjny przy giętno-skrętnej utracie stateczności $\chi_{F T}$ elementu nieidealnego wyznaczany jest więc w zaproponowanym ujęciu analogicznie jak w normie [10]:

$$
\chi_{F T}=\left(\phi_{F T}+\sqrt{\phi_{F T}^{2}-\bar{\lambda}_{F T}^{2}}\right)^{-1}, \quad \phi_{F T}=0,5\left(1+\alpha_{F T}\left(\bar{\lambda}_{F T}-0,2\right)+\bar{\lambda}_{F T}^{2}\right)
$$

gdzie: $\quad \bar{\lambda}_{F T}-$ smukłość względna elementu ściskanego i zginanego ulegającego niestateczności giętno-skrętnej:

$$
\bar{\lambda}_{F T}=\sqrt{\frac{\alpha_{M N, R k}}{\alpha_{M, c r}}}
$$

$\alpha_{F T}-$ parametr imperfekcji. 
Parametr imperfekcji wyznacza się z nieliniowej interpolacji jak w [7]:

$$
\alpha_{F T}=\frac{\alpha_{L T}}{1+\alpha_{n}}+\frac{\alpha_{i}}{1+\alpha_{m}}
$$

w którym: $\alpha_{L T}, \alpha_{i}$ - parametry imperfekcji Maquoi-Rondala, odpowiednio w odniesieniu do krzywej niestateczności przy zwichrzeniu (zgodnie z przypadkiem ogólnym wg 6.3.2.2 [10]) oraz krzywej niestateczności przy wyboczeniu (zgodnie z [10]), przy czym $\alpha_{i}=\alpha_{y}$, gdy decyduje wyboczenie giętne względem osi $y-y$ lub $\alpha_{i}=\alpha_{z}$, gdy decyduje wyboczenie giętne względem osi $z-z$ albo wyboczenie skrętne, $\alpha_{n}, \alpha_{m}$ - parametry aktualnego stanu efektów oddziaływań:

$$
\alpha_{n}=\frac{n_{E d, 0}}{m_{y, E d, 0}}, \quad \alpha_{m}=\frac{1}{\alpha_{n}}
$$

gdzie: $n_{E d, 0}, m_{y, E d, 0}-$ bezwymiarowe wartości aktualnego stanu efektów oddziaływań:

$$
n_{E d, 0}=\frac{N_{E d}}{N_{c, R k}}, \quad m_{y, E d, 0}=\frac{M_{y, E d}}{M_{c y, R k}}
$$

Nośności przekroju $N_{c, R k}, M_{c y, R k}$, odpowiednio przy ściskaniu i zginaniu względem osi większej bezwładności, zależne są od klasy przekroju i wyznaczane zgodnie z normą [10].

Kryterium nośności elementu, w zaproponowanym ujęciu, ma postać:

$$
\alpha_{b, R d}=\frac{\alpha_{b, R k}}{\gamma_{M 1}} \geq 1
$$

gdzie: $\gamma_{M 1}$ jest współczynnikiem częściowym do nośności elementu o wartości $\gamma_{M 1}=1,0$ zgodnie z załącznikiem krajowym do normy [10].

\section{Analiza stateczności sprężystej przy zwichrzeniu oraz nośności elementu nieidealnego ściskanego i zginanego przy płaskim zginaniu}

Mnożnik obciążenia $\alpha_{M, c r}$ odpowiadający stanowi krytycznemu przy zginaniu ze zwichrzeniem bez udziału siły osiowej wyznacza się z zależności: 


$$
\alpha_{M, c r}=\frac{M_{c r}}{M_{y, E d}}=\frac{m_{y, c r}}{m_{y, E d, 0}}
$$

gdzie: $M_{c r}$ - sprężysty moment krytyczny zwichrzenia, który można wyznaczać analitycznie (np. wykorzystując zależności podane w $[8,13,15]$ i wielu innych) lub numerycznie np. z wykorzystaniem darmowego oprogramowania LTBeam.

$\mathrm{W}$ praktyce projektowej, przy wyznaczaniu analitycznym momentu krytycznego $M_{c r}=\min M_{c r, i}$, rozpatruje się wydzielone segmenty ,, ” belki między usztywnieniami poprzecznymi. Moment krytyczny odnosi się więc do „krytycznego segmentu" o warunkach brzegowych odpowiadających widełkowemu podparciu. W podejściu analityczno-numerycznym zaproponowanym w niniejszej pracy przyjęto, że mnożnik obciążenia przy zwichrzeniu $\alpha_{M, c r}$ elementu $\mathrm{z}$ pośrednimi usztywnieniami bocznymi wyznacza się numerycznie z programu LTBeam. Ta wartość może być większa od kilku do kilkudziesięciu procent od wartości wyznaczonej w odniesieniu do „segmentu krytycznego".

Mnożnik obciążenia $\alpha_{M N, R k}$ odpowiadający stanowi granicznemu ściskania i zginania II rzędu z imperfekcjami (bez uwzględnienia stanu zwichrzenia) można wyznaczyć wykorzystując formuły uwzględniające sumowanie trzech wskaźników wykorzystania nośności: dwóch dotyczących zginania elementu idealnego: zginania I rzędu $\left(U_{M y}\right)$, zginania od efektu II rzędu $P-\delta_{z}\left(U_{P-\delta z}\right)$ oraz trzeciego dotyczącego ściskania elementu z imperfekcjami $\left(U_{i m p}\right)$ :

$$
U_{M y}+U_{P-\delta_{z}}+U_{i m p}=1
$$

W odniesieniu do swobodnie podpartych w płaszczyźnie XZ elementów o przekrojach klasy 1 i 2, osiowo ściskanych i zginanych dwoma momentami podporowymi o różnym znaku i wartości, składniki wyrażenia (12) mają postać:

- zginanie II rzędu jako suma $U_{M y}$ zginania I rzędu oraz $U_{P-\delta z}$ od efektu $P-\delta_{z}$ :

a) $0 \leq \alpha_{n} \leq 0,5 a$

$$
\begin{aligned}
& U_{M y}=0,5 \alpha_{M N, R k} m_{y, E d, 0}\left[1+\psi_{y}+\left(1-\psi_{y}\right)\left(1-\xi_{\max }\right)\right] \\
& U_{P-\delta_{z}}=\alpha_{M N, R k} n_{E d, 0}\left[\beta_{\delta} \eta_{E d, y} \bar{w}_{1}\left(\xi_{\max }\right)+\beta_{\delta 2} \eta_{E d, y, 2} \bar{w}_{2}\left(\xi_{\max }\right)\right]
\end{aligned}
$$

b) $0,5 a \leq \alpha_{n}$

$$
U_{M y}=0,5 \alpha_{M N, R k} m_{y, E d, 0} \frac{1-\alpha_{M N, R k} n_{E d, 0}}{1-0,5 a}\left[1+\psi_{y}+\left(1-\psi_{y}\right)\left(1-\xi_{\max }\right)\right]
$$




$$
\begin{aligned}
U_{P-\delta_{z}}= & \alpha_{M N, R k} n_{E d, 0} \frac{1-\alpha_{M N, R k} n_{E d, 0}}{1-0,5 a}\left[\beta_{\delta} \eta_{E d, y} \bar{w}_{1}\left(\xi_{\max }\right)+\right. \\
& \left.\beta_{\delta 2} \eta_{E d, y, 2} \bar{w}_{2}\left(\xi_{\max }\right)\right]
\end{aligned}
$$

- wpływ imperfekcji na wytężenie elementu ściskanego $U_{\text {imp }}$ :

a) gdy $\min \left(\chi_{i}\right)=\chi_{y}$

$$
U_{i m p}=\alpha_{y}\left(\bar{\lambda}_{y}-0,2\right) \alpha_{M N, R k} n_{E d, 0} \frac{\bar{w}_{1}\left(\xi_{\max }\right)}{\left(1-\alpha_{M N, R k} n_{E d, 0}\right)\left(1-\bar{\lambda}_{y}^{2} \alpha_{M N, R k} n_{E d, 0}\right)}
$$

b) $\operatorname{gdy} \min \left(\chi_{i}\right)=\chi_{z}$

$$
U_{i m p}=\alpha_{z}\left(\bar{\lambda}_{z}-0,2\right) \alpha_{M N, R k} n_{E d, 0} \frac{1}{\left(1-\alpha_{M N, R k} n_{E d, 0}\right)\left(1-\bar{\lambda}_{z}^{2} \alpha_{M N, R k} n_{E d, 0}\right)}
$$

c) $\operatorname{gdy} \min \left(\chi_{i}\right)=\chi_{T}$

$$
U_{i m p}=\alpha_{z}\left(\bar{\lambda}_{T}-0,2\right) \alpha_{M N, R k} n_{E d, 0} \frac{1}{\left(1-\alpha_{M N, R k} n_{E d, 0}\right)\left(1-\bar{\lambda}_{T}^{2} \alpha_{M N, R k} n_{E d, 0}\right)}
$$

gdzie: $\psi_{y}=M_{y, E d, \text { supp,min }} / M_{y, E d, \text { supp,max }}-$ współczynnik proporcji podporowych momentów zginających, gdzie $M_{y, E d \text {,supp,max }}$ oraz $M_{y, E d \text {,supp,min są odpo- }}$ wiednio maksymalnym i minimalnym podporowym momentem zginającym,

$\xi_{\max }$ - bezwymiarowa rzędna $\xi$ odnosząca się do najbardziej wytężonego przekroju elementu przy założeniu $\xi=2 x / L$, gdzie $L$ jest długością elementu,

$a$ - parametr kształtu do interakcyjnej nośności plastycznej przekroju określany zgodnie z normą [10],

$\beta_{\delta}, \beta_{\delta 2}$ - współczynniki amplifikacji odpowiadające przybliżonemu uwzględnieniu efektów II rzędu $\left(P-\delta_{z}\right)$ przy zginaniu względem osi $y-y$, w których $\bar{\lambda}_{i}$ jest związane z najmniejszym współczynnikiem redukcyjnym $\chi_{i}=\min \left(\chi_{y}, \chi_{z}, \chi_{T}\right)$ :

$$
\beta_{\delta}=\frac{1}{1-\bar{\lambda}_{i}^{2} \alpha_{M N, R k} n_{E d, 0}}, \quad \beta_{\delta 2}=\frac{1}{1-0,25 \bar{\lambda}_{i}^{2} \alpha_{M N, R k} n_{E d, 0}}
$$

Pozostałe oznaczenia wyjaśniono w pracy [4] i nie będą tutaj przywoływane. 


\section{Przykłady krzywych nośności granicznej elementów ściskanych i zginanych}

Rozpatrzono dwa przykłady swobodnie podpartego elementu ściskanego i jednokierunkowo zginanego momentami podporowymi względem osi większej bezwładności $y$-y (w dwóch wariantach proporcji momentów podporowych $\psi_{y}=1$ oraz $\psi_{y}=-1$ ), wykonanych z kształtowników IPE 360 oraz HEB 300 ze stali S 235, dyskretnie podpartych bocznie i przeciwskrętnie w równych odstępach tak, aby smukłości względne przy wyboczeniu giętnym względem osi $z-z$ wydzielonych segmentów wynosiły $\bar{\lambda}_{z}=1,0$. Na rysunku 2. przedstawiono schematy statyczne analizowanych elementów wraz z rozmieszczeniem sztywnych dyskretnych podparć bocznych i przeciwskrętnych.

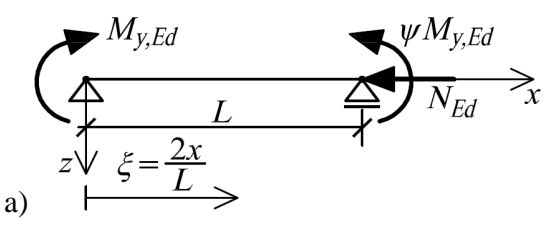

b)

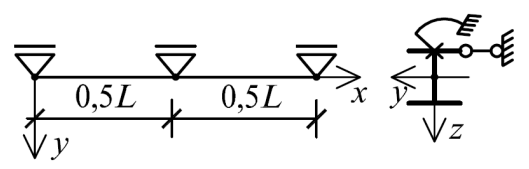

c)

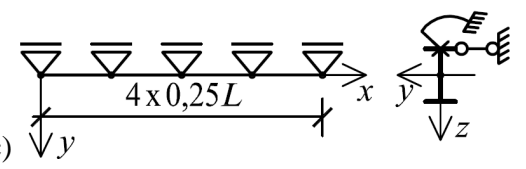

Rys. 2. Schemat statyczny, a) ogólny schemat obciążenia, b) element o przekroju HEB 300, c) element o przekroju IPE 360

Fig. 2. Static scheme, a) general loading case, b) beam-column of HEB 300 section, c) beamcolumn of IPE 360 section

Tabela 1. Zestawienie smukłości względnych analizowanych elementów

Table 1 . Summary of element slenderness ratios

\begin{tabular}{|c|c|c|c|c|c|c|}
\hline Kształtownik & $\bar{\lambda}_{\boldsymbol{y}}$ & $\bar{\lambda}_{z}$ & $\bar{\lambda}_{\boldsymbol{T}}$ & $\begin{array}{c}\bar{\lambda}_{\boldsymbol{L T}} \\
\left(\boldsymbol{\psi}_{\boldsymbol{y}}=\mathbf{1}\right)\end{array}$ & $\begin{array}{c}\bar{\lambda}_{\boldsymbol{L T}} \\
\left(\boldsymbol{\psi}_{\boldsymbol{y}}=\mathbf{- 1}\right) \\
\boldsymbol{M}_{\boldsymbol{c} r} \\
\text { analitycznie }\end{array}$ & $\begin{array}{c}\bar{\lambda}_{\boldsymbol{L T}} \\
\left(\boldsymbol{\psi}_{\boldsymbol{y}}=\mathbf{- 1}\right) \\
\boldsymbol{M}_{\boldsymbol{c r}} \\
\text { numerycznie }\end{array}$ \\
\hline HEB 300 & 1,167 & 1,000 & 0,602 & 0,709 & 0,524 & 0,489 \\
\hline IPE 360 & 1,013 & 1,000 & 0,706 & 0,801 & 0,696 & 0,623 \\
\hline
\end{tabular}

W tabeli 1. zestawiono smukłości względne analizowanych elementów. Smukłość względną przy zwichrzeniu $\bar{\lambda}_{L T}$ wyznaczono w dwóch wariantach. W pierwszym $M_{c r}$ wyznaczono analitycznie jako min $M_{c r, i}$, gdzie $M_{c r, i}$ określono zgodnie z propozycją przedstawioną w [8] w odniesieniu do segmentów wydzielonych pośrednimi stężeniami bocznymi. W drugim $M_{c r}$ wyznaczono nume- 
rycznie za pomocą programu LTBeam $\mathrm{w}$ odniesieniu do całego elementu, a więc $\mathrm{z}$ uwzględnieniem ciągłości kąta obrotu $\theta_{z}$ i deplanacji $\mathrm{d} \theta_{x} / \mathrm{d} x$ w punktach rozmieszczenia stężeń pośrednich. Należy zwrócić uwagę, że w przypadku symetrii zginania $\left(\psi_{y}=1\right)$ wartość $M_{c r}$ jest praktycznie identyczna w podejściu analitycznym i numerycznym, dlatego w tabeli 1 podano tylko jedną wspólną wartość smukłości względnej przy zwichrzeniu. W przypadku antysymetrii zginania $\left(\psi_{y}=-1\right)$, smukłości otrzymane z wykorzystaniem $M_{c r}$ wyznaczonego numerycznie są mniejsze niż smukłości względne wyznaczone $\mathrm{z}$ wykorzystaniem $M_{c r}$ obliczonego analitycznie. Mniejsze smukłości prowadzą do uzyskania większych nośności na zwichrzenie, przy czym w przypadku przekroju HEB 300 jest to nośność większa o ok. 1,5\% zaś w przypadku przekroju IPE 360 o ok. 5\%. Do wyznaczenia przedstawionych dalej krzywych granicznych nośności przyjęto $M_{c r}$ obliczane numerycznie z wykorzystaniem programu LTBeam.

Analizowany przekrój HEB 300 jest przy ściskaniu przekrojem klasy 1, przekrój IPE 360 zaś jest klasy 2 (najniekorzystniejszy przypadek obciążenia). Przekroje mogą być traktowane odpowiednio jako klasy 1 i 2 w odniesieniu do dowolnej proporcji momentu zginającego i osiowej siły ściskającej (wytyczne do wyznaczenia klasy przekroju równocześnie ściskanego i zginanego podano w poradniku [13]). Nośność przekroju HEB 300 wynosi przy ściskaniu $N_{c, R k}=A f_{y}=149,1 \cdot 23,5=3504 \mathrm{kN}$ oraz przy zginaniu względem osi $y-y$ $M_{c y, R k}=W_{p l, y} f_{y}=1869 \cdot 23,5=43920 \mathrm{kNcm}=439,2 \mathrm{kNm}$. Nośność przekroju IPE 360 wynosi przy ściskaniu $N_{c, R k}=A f_{y}=72,7 \cdot 23,5=1708 \mathrm{kN}$ oraz przy zginaniu względem osi $y-y M_{c y, R k}=W_{p l, y} f_{y}=1019 \cdot 23,5=23950 \mathrm{kNcm}=239,5 \mathrm{kNm}$. Parametr kształtu do interakcyjnej nośności plastycznej przekroju HEB 300 wynosi $a=0,235$ zaś przekroju IPE 360 wynosi $a=0,406$.

W odniesieniu do analizowanych przypadków elementów, współczynniki redukcyjne związane $\mathrm{z}$ decydującą formą wyboczenia oraz odpowiadający jej parametr imperfekcji wynoszą:

- HEB 300: $\chi_{i}=\min \left(\chi_{y} ; \chi_{z} ; \chi_{T}\right)=\min (0,496 ; 0,540 ; 0,784)=0,496$, przyjęto: $\alpha=\alpha_{y}=0,34$ oraz $\alpha_{L T}=0,21$,

- IPE 360: $\chi_{i}=\min \left(\chi_{y} ; \chi_{z} ; \chi_{T}\right)=\min (0,657 ; 0,597 ; 0,780)=0,597$, przyjęto: $\alpha=\alpha_{z}=0,34$ oraz $\alpha_{L T}=0,34$.

Obliczenia numeryczne i analityczne wykonano w dwóch wariantach proporcji momentów podporowych (symetrii zginania $\psi_{y}=1$ oraz antysymetrii zginania $\left.\psi_{y}=-1\right) \mathrm{w}$ odniesieniu do wybranych parametrów proporcji ściskającej siły osiowej i większego zginającego momentu podporowego $\alpha_{n}$ i $\alpha_{m}$, a otrzymane rezultaty w postaci dyskretnej połączono tworząc krzywe graniczne. Na rysunkach 3-4 otrzymane $\mathrm{z}$ proponowanej metody analitycznonumerycznej krzywe nośności granicznej porównano z krzywymi eurokodowymi wyznaczonymi zarówno Metodą 1 jak i Metodą $2 \mathrm{w}$ dwóch przypadkach: a) przypadek ogólny - gdy efekty zwichrzenia oszacowane są zgodnie z podejściem ogólnym wg 6.3.2.2 normy [10], 
b) przypadek szczególny - gdy efekty zwichrzenia oszacowane są zgodnie z podejściem wg 6.3.2.3 normy [10], przeznaczonym do oceny nośności dwuteowników walcowanych i ich odpowiedników spawanych.
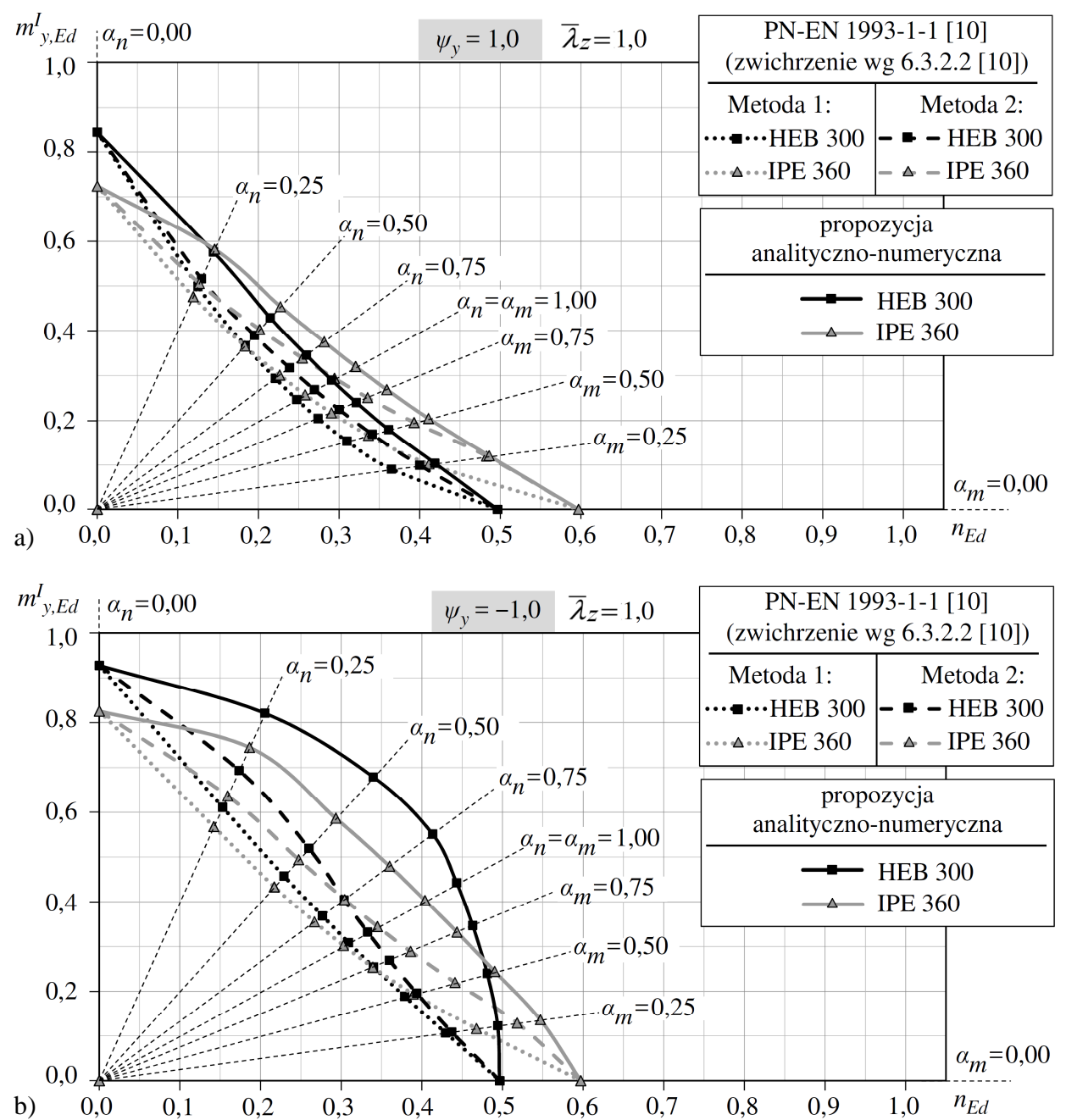

Rys. 3. Porównanie krzywych nośności wyboczeniowej w bezwymiarowych współrzędnych $n_{E d}$ oraz $m_{y, E d}$ (przypadek ogólny - zwichrzenie zgodnie z 6.3.2.2 [10]), a) zginanie symetryczne $\left.\left(\psi_{y}=1\right), \mathrm{b}\right)$ zginanie antysymetryczne $\left(\psi_{y}=-1\right)$

Fig. 3. Comparison of buckling resistance curves in dimensionless coordinates $n_{E d}$ and $m_{y, E d}$ (general case - lateral-torsional buckling according to 6.3.2.2 [10]), a) symmetric bending $\left.\left(\psi_{y}=1\right), \mathrm{b}\right)$ antisymmetric bending $\left(\psi_{y}=-1\right)$ 

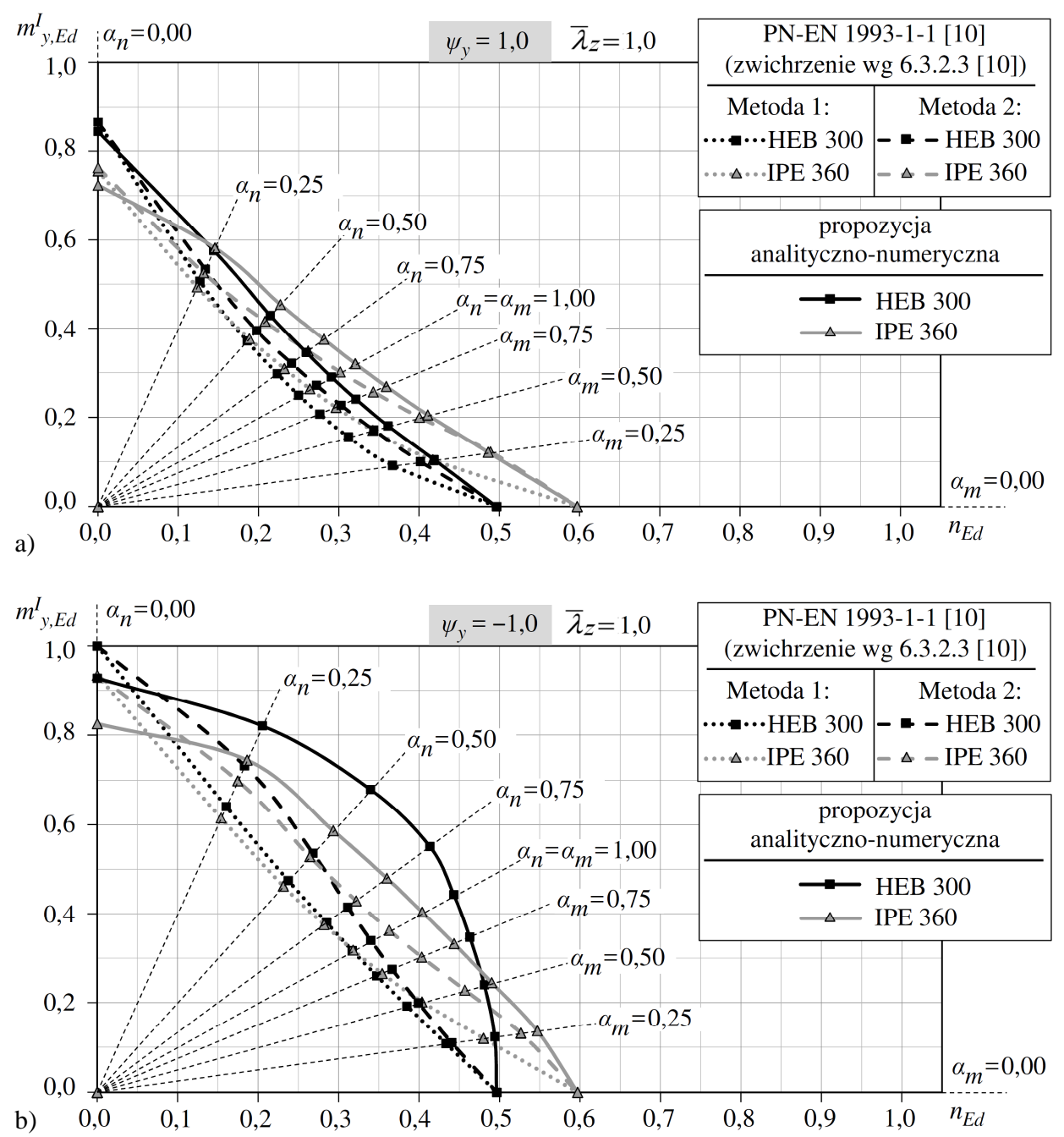

Rys. 4. Porównanie krzywych nośności wyboczeniowej w bezwymiarowych współrzędnych $n_{E d}$ oraz $m_{y, E d}$ (przypadek szczególny - zwichrzenie zgodnie z 6.3.2.3 [10]), a) zginanie symetryczne $\left(\psi_{y}=1\right)$, b) zginanie antysymetryczne $\left(\psi_{y}=-1\right)$

Fig. 4. Comparison of buckling resistance curves in dimensionless coordinates $n_{E d}$ and $m_{y, E d}$ (special case - lateral-torsional buckling according to 6.3.2.3 [10]), a) symmetric bending $\left.\left(\psi_{y}=1\right), \mathrm{b}\right)$ antisymmetric bending $\left(\psi_{y}=-1\right)$ 
Z porównania wynika, że nośności uzyskane z proponowanej metody analityczno-numerycznej są powyżej otrzymanych z interakcyjnych formuł eurokodowych, w których współczynniki interakcji wyznacza się Metodą 1 oraz Metodą $2 \mathrm{w}$ obu przypadkach (ogólny i szczególny) szacowania efektów zwichrzenia. Tylko w przypadku szczególnym szacowania zwichrzenia i małych wartości siły podłużnej $n_{E d}$ obserwuje się większą nośność z formuł eurokodowych. Związane jest to z tym, że w przypadku małych wartości siły ściskającej przeważający wpływ na nośność elementu ma efekt zwichrzenia, który szacowany w przypadku szczególnym zgodnie z 6.3.2.3 normy [10] ma mniejszy wpływ na redukcję nośności elementu niż to wynika $\mathrm{z}$ przypadku ogólnego zgodnego z 6.3.2.2 [10]. W związku z tym tylko w przypadku ogólnym, gdy $n_{E d}=0$ otrzymuje się tą samą nośność na zwichrzenie z proponowanej metody i formuł eurokodowych. Warto zwrócić uwagę, że w przypadku $m_{y, E d}=0$, gdy element podlega tylko ściskaniu, to z obu podejść otrzymuje się taką samą nośność na wyboczenie.

Dodatkowo krzywe nośności otrzymane z proponowanej metody analityczno-numerycznej są bliższe krzywym eurokodowym w przypadku szczególnym szacowania efektów zwichrzenia. Największe różnice pomiędzy proponowaną metodą, a formułami eurokodowymi występują w przypadku antysymetrii momentu zginającego $\left(\psi_{y}=-1\right)$, w przypadku symetrii momentu zginającego $\left(\psi_{y}=1\right)$ obserwuje się tylko niewielką kilkuprocentową różnicę w otrzymanych wartościach nośności. Duże różnice w odniesieniu do antysymetrii momentu zginającego związane są z dość konserwatywnym ujęciem przez normę [10] oceny nośności elementów z podparciem pośrednim, szczególnie przy dużym gradiencie momentu zginającego wzdłuż elementu. Warto również zwrócić uwagę, że w odniesieniu do analizowanych przypadków, krzywe nośności granicznej uzyskane z Metody 2 są powyżej otrzymanych z Metody 1, co oznacza, że Metoda 2 jest w odniesieniu do analizowanych przypadków elementów pośrednio stężonych mniej konserwatywna niż Metoda 1 . W odniesieniu do elementów bez pośredniego podparcia bocznego i przeciwskrętnego zazwyczaj obserwuje się sytuację odwrotną i to Metoda 1 jest mniej konserwatywna w porównaniu do Metody 2 szczególnie wtedy gdy wzrasta gradient momentu zginającego wzdłuż elementu [5].

\section{Podsumowanie}

Przedstawiono propozycję metody analityczno-numerycznej oceny nośności elementów ściskanych i jednokierunkowo zginanych względem osi większej bezwładności przekroju o dyskretnych podporach bocznych rozmieszczonych w jednakowych odstępach (przeciwtranslacyjnych i przeciwskrętnych). Zaproponowana metoda jest uogólnieniem metody Ayrton-Perry'ego [7] na przypadek równoczesnego ściskania i zginania elementu, co pozwala na wyznaczenie współczynnika redukcyjnego z uwagi na niestateczność ogólną w sposób analo- 
giczny do przyjętego w [10] do wyboczenia prętów jedynie ściskanych lub zwichrzenia prętów wyłącznie zginanych w płaszczyźnie większej bezwładności przekroju. Zaproponowana metoda $\mathrm{w}$ odniesieniu do elementów pośrednio stężonych ma równie prostą interpretację graficzną co metoda opracowana do oceny nośności elementów bez pośrednich stężeń (rysunek 1). Dużą zaletą zaproponowanej metody analityczno-numerycznej jest stosowanie tylko jednego kryterium nośności elementu (10) zamiast przedstawionych w [10] dwóch interakcyjnych formuł nośności wyboczeniowej elementu (gdzie współczynniki interakcyjne wyznacza się Metodą 1 lub rekomendowaną w załączniku krajowym Metodą 2) oraz interakcyjnego warunku nośności dotyczącego weryfikacji nośności przekroju. Ponadto, w przedstawionej metodzie proponuje się odejście od koncepcji tzw. równoważnego stałego momentu, który w podejściu eurokodowym pełni istotną rolę w ocenie nośności elementu, szczególnie gdy występuje moment zginający o znacznym gradiencie na długości elementu.

Zaproponowaną koncepcję oceny nośności zilustrowano na przykładzie elementów o dwóch różnych proporcjach $h / b$ dwuteowego przekroju kształtownika walcowanego, HEB 300 o $h / b \leq 1,2$ oraz IPE 360 o $h / b>1,2$, swobodnie podpartych na końcach oraz z dyskretnymi usztywnieniami pośrednimi bocznymi i przeciwskrętnymi. Porównano krzywe graniczne technicznej utraty stateczności otrzymane z proponowanej metody analityczno-numerycznej z krzywymi otrzymanymi $\mathrm{z}$ eurokodowych formuł interakcyjnych. W odniesieniu do formuł eurokodowych współczynniki interakcji wyznaczono dwoma metodami - Metodą 1 oraz rekomendowaną w załączniku krajowym do [10] Metodą 2, gdzie efekty zwichrzenia szacowano w dwóch przypadkach - ogólnym zgodnie z 6.3.2.2 [10] i szczególnym zgodnie z 6.3.2.3 [10].

Stwierdzono, że w przypadku analizowanych elementów krzywe nośności wyboczenia technicznego otrzymane $\mathrm{z}$ proponowanej metody analitycznonumerycznej są $\mathrm{w}$ przeważającym obszarze powyżej otrzymanych $\mathrm{z}$ formuł eurokodowych, przy czym różnice te są największe w odniesieniu do antysymetrii momentu zginającego $\left(\psi_{y}=-1\right)$. Należy jednak zwrócić uwagę, że w przypadku antysymetrii momentu zginającego $\left(\psi_{y}=-1\right)$ i elementów bez dodatkowych pośrednich stężeń, krzywe nośności otrzymane z proponowanej metody są porównywalne lub poniżej otrzymanych $\mathrm{z}$ formuł eurokodowych $[4,5]$. Ponadto zauważono, że w przypadku rozważanych elementów pośrednio stężonych, z eurokodowej Metody 2 otrzymuje się mniej konserwatywne rozwiązanie niż z Metody 1, szczególnie przy gradiencie momentu zginającego odpowiadającym współczynnikowi $-1 \leq \psi_{y}<0$.

W związku z zauważonymi różnicami w otrzymanych wynikach między proponowaną metodą analityczno-numeryczną, a eurokodowymi metodami oceny nośności, w kolejnym etapie badań przewidziano weryfikacyjne analizy numeryczne GMNIA (geometrycznie i materiałowo nieliniowe z uwzględnieniem wpływu imperfekcji). 


\section{Literatura}

[1] Ayrton W.E., Perry J., On struts, The Engineer, 62 (1886), pp. 464-465.

[2] Boissonnade A., Jaspart J.-P., Muzeau J.-P., Villette M.: New interaction formulae for beam-columns in Eurocode 3: The French-Belgian approach, Journal of Constructional Steel Research 60 (2004), pp. 421-431.

[3] Bijlaard F., Feldmann M., Naumes J., Sedlacek G., The "general method" for assessing the out-of-plane stability of structural members and frames and the comparison with alternative rules in EN 1993 - Eurocode 3 - Part 1-1, Steel Construction 3 (1) (2010), pp. 19-33.

[4] Giżejowski M., Stachura Z., A consistent Ayrton-Perry approach for the flexuraltorsional buckling resistance evaluation of steel I-section members. Civil and Environmental Engineering Reports 2 (2017), w druku.

[5] Giżejowski M., Stachura Z., Ocena nośności stalowych elementów dwuteowych przy wyboczeniu giętno-skrętnym w kontekście nowelizacji eurokodów dotyczących konstrukcji, Inżynieria i Budownictwo, nr 6 (2017), w druku.

[6] Gizejowski M., Stachura Z.: Buckling strength of a steel multi-storey framework according to Eurocode's general method. In: Recent Progress in Steel and Composite Structures (eds. M. Gizejowski, A. Kozlowski, J. Marcinowski \& J. Ziolko), London. Taylor \& Francis Group 2016, pp. 154-155, e-book on CD, pp. 381-391.

[7] Gizejowski M., Stachura Z.: Generalized Ayrton-Perry approach for the evaluation of beam-column resistance. In: Insights and Innovations in Structural Engineering, Mechanics and Computation (ed. A. Zingoni), London, Taylor \& Francis Group, 2016, pp. 253-254, e-book on CD, pp. 713-719.

[8] Gizejowski M.A., Stachura Z., Uziak J.: Elastic flexural-torsional buckling of beams and beam-columns as a basis for stability design of members with discrete rigid restraints. In: Insights and Innovations in Structural Engineering, Mechanics and Computation (ed. A. Zingoni), London, Taylor \& Francis Group 2016, pp. 261-262, e-book on CD, pp. 738-744.

[9] Greiner R., Lindner J.: Interaction formulae for members subjected to bending and axial compression in Eurocode 3 - the Method 2 approach, Journal of Constructional Steel Research 62 (2006), pp. 757-770.

[10] PN-EN 1993-1-1:2005, Projektowanie konstrukcji stalowych - Część 1-1: Reguły ogólne.

[11] Papp F.: Buckling assessment of steel members through overall imperfection method. Engineering Structures 106 (2016), pp. 124-136.

[12] Rondal J., Maquoi R., Le Flambement des Collonnes en Acier, Notice 1091, Chambre Syndicale des Fabricants de Tubes d'Acier, Paris, France (1980).

[13] Simoes da Silva L., Simoes R., Gervasio H.: Design of Steel Structures, Eurocode 3: Design of Steel Structures, Part 1-1: General Rules and Rules for Buildings (2nd edition), ECCS Eurocode Design Manual, Ernst \& Sohn, Berlin 2010.

[14] Tankova T., Marques L., Andrade A., Simoes da Silva L.: A consistent methodology for the out-of-plane buckling resistance of prismatic steel beam-columns. Journal of Constructional Steel Research, 128 (2017), pp. 839-852.

[15] Trahair N.S., Bradford M.A, Nethercot D.A., Gardner L., The behaviour and design of steel structures to EC3 (4th edition). Taylor \& Francis, London - New York 2008. 


\section{AN ALTERNATIVE ANALYTICAL-NUMERICAL PROCEDURE IN EUROCODE'S DESIGN OF STEEL MEMBERS WITH DISCRETE LATERAL AND TORSIONAL IN-SPAN RESTRAINTS}

\section{S u m m a r y}

An alternative Eurocode's procedure of analytical-numerical Ayrton-Perry type is proposed for the assessment of buckling resistance of steel elements subjected to compression and bending about the major principal cross section axis. This paper is a further authors' contribution that this time is extended for the effect of discrete lateral and torsional in-span restraints on the beamcolumn resistance evaluation. Authors' proposal, using the parameters predicted partially in an analytical way and partially in a numerical way can be treated as a generalisation of AyrtonPerry formulation adopted in PN-EN 1993-1-1, that originally addressed the flexural buckling of imperfect compressed members. In PN-EN 1993-1-1 this formulation was also applied to lateraltorsional buckling of imperfect members bent mono-axially about the stronger axis but not extended to all the overall buckling problems associated with combined compression and bending. A detailed explanation is presented using examples of HEB and IPE I-section steel members under compression and moment gradient about the stronger cross section principal axis. Obtained results for different load effects proportion in the domain of the axial compressive force and the bending moment about the section stronger axis are compared with results based on the Eurocode's formulation based on the interaction equations of the axial force and bending moment according to Method 1 and Method 2.

Keywords: steel I-section, beam-column, buckling resistance, generalized Ayrton-Perry formulation, discrete lateral and torsional restraints

Przestano do redakcji: 11.04.2017 $r$.

Przyjęto do druku: 01.09.2017 r. 